DOI 10.14746/ssp.2019.2.2

\title{
Tadeusz JANICKI
}

Adam Mickiewicz Uniwersity in Poznań

ORCID: 0000-0001-7009-6181

\section{Farmland and people as essential resources of Poland in the concepts of Polish agrarians (1931-1946)}

\begin{abstract}
Abstrakt: Agrarianism was founded in Germany in the second half of the nineteenth century, but it exercised the greatest influence in the predominantly agricultural countries of Central and Eastern Europe. Central European agrarianism was the ideology of peasants and it proclaimed that land was the greatest wealth of the nation, agriculture was the most important branch of economy, and peasants were the morally healthiest and thus the most valuable part of the society. Agrarianism was a personalist ideology, which proclaimed a conception of man as a subject of social and economic life. It criticized both extreme liberalism and totalitarian political ideology and advocated the concept of a 'third way of development' - between capitalism and communism. The main purpose of this paper is to analyze the formation and development of Polish agrarianism, and the related process of transfer and reception of knowledge. The analysis focuses on the concept of land, man and labor, formulated by the representatives of the mainstream of agrarianism. In the 1930s, the Polish agrarians voiced demands for land reform and the development of smallholder agriculture which, in their opinion, made an optimal use of the land, capital and labor, that is, the most important resources available to interwar Poland.
\end{abstract}

Key words: agrarianism, a third way, soil, work, transfer of knowledge

$\mathbf{T}$ he origins of Polish agrarian thought were connected with the foundation of the first peasant parties and their activities at the turn of the nineteenth and twentieth centuries. Their demands to 'raise peasants' in terms of nation, politics, economics and civilization, together with the assumptions proclaiming the peculiar mission of peasants in the process of transformation of social relations on Polish land became a permanent part of the subsequent agrarian ideology.

In its mature form, formulated in the early 1930s, this ideology consistently glorified the country, peasants and agriculture, and its principal purpose, apart from the political and economic empowerment of peasants, 
was the formation of a new democratic socio-economic system based on land, work, cooperative movements and economic self-governance. It was a personalist ideology that stressed the existential equality of all members of society and the need to create conditions that would guarantee equal rights to everybody. It criticized both extreme liberalism and totalitarian political concepts, and advocated the concept of a 'third way of development' between capitalism and communism. Agrarianism was founded in Germany in the second half of the nineteenth century, but its greatest influence was in the predominantly agricultural countries of Central and Eastern Europe.

The purpose of this paper is to analyze the formation and development of Polish agrarianism, and the related process of transfer and reception of knowledge from the countries where agrarianism developed earlier, namely Denmark, Switzerland and Czechoslovakia. Since this study is short, the center of the considerations are the views of the representatives of the main current in Polish agrarianism i.e. so-called Wici [Rural Youth] agrarianism. The analysis focuses on the concepts of land, man and labor, formulated by the representatives of this political trend, which in their opinion, were the most important resources and the basis for economic development in the interwar Poland, as well as the resulting vision of the relationships between man and nature. ${ }^{1}$ According to the agrarians, the optimal use of these factors by peasants working on their own farms, combined with the cooperative movement, economic self-governance and general education was to become the basis for the broader modernization of Poland.

The paper attempts to present a deeper analysis of the essential section of the agrarian ideology concerning land, work and relations between people working on farmland and the surrounding nature which, until recently, played a peripheral role in the general considerations concerning this political concept.

In spite of the harsh criticism of this ideology from the very first days of its formulation in the 1930s by both the left and the right side of the political scene, and later by the academic community, it is necessary to say

1 The ideas comprising the above concept were understood by agrarians in the following way: the idea of land (land is a natural property of the people and it should belong to those who work on it); the idea of man (an ideal of a man is a peasant, a farmer, a peasant activist - hard-working, morally impeccable, attached to tradition and surrounding nature), the idea of labor (it is only through work, ideally on the land, that a man becomes a full member of society). 
that the agrarians properly assessed the character as well as the good and bad aspects of the Polish economy of the 1930s. They proposed a thesis that, in the face of a crisis of industrial capitalism, a collapse of international division of labor and the lack of investment capital, the chances for the economic recovery of Poland could be found in the development of the domestic market by making use of available land and work resources, an argument which deserves a positive appraisal.

Despite the allegations of being anachronistic or economically dilettantish, the agrarians' concept considering the macroeconomic conditions of the time became an original, rational attempt to find a way out of the difficult socio-economic situation of Poland. The agrarians themselves described their concept as looking for a third way between, in their opinion, a discredited capitalism, and communism, depriving people of liberty and property.

The presentation and analysis of the process of formation of the program section of Polish agrarians, which emphasizes the significance of people, land and work as essential economic resources of Poland in the 1930s and 1940s, presented in this article, was based on descriptive, genetic and comparative methods.

The chronological framework of the considerations is the period from the early 1930s (when the concept of agrarianism to identify a specific worldview first appeared in the journal Wici, in the second half of 1931) until the adoption of the agrarianism-based manifesto by the Polish People's Party in January 1946.

The source database contains works by agrarian theoreticians (especially by Stanisław Miłkowski); press of the Peasant Movement; printed sources; studies, particularly the works by Borkowski (1966), Chrobak (1998), Dąbrowski (1981), Golec (1994), Jachymek (1993), Lech (1991), Piątkowski (1993), Wojas (1983), and Ziembiński (1960) and a group of articles published in the double issue of the Annals of Peasant Movement History of 1983/4 and the magazine The Country and the State in 1990-1991.

The beginnings of agrarianism on the Polish lands were related to the articles published in the magazine Zaranie, and the related zaraniarski ('zaranian') movement that existed in the Polish Kingdom in 1907-1914, and the activities of peasant parties in Galicia at the turn of the nineteenth and twentieth centuries. After World War I, agrarian ideas found supporters, especially in the academic community and also among members of rural youth organizations, which contributed to the popularization of 
agrarianism, and consequently to the creation of a unique Polish variety of this ideology.

At the turn of the centuries, and in the 1920s the primary impetus for the development of Polish agrarianism was the reception of the Czech and Slovak, and to a lesser extent, Bulgarian, Yugoslav and Danish ideas of peasant emancipation and concepts of the modernization of agriculture and rural areas. They spread into the Polish territory in three ways. Firstly, by the agency of academics and thinkers dealing with agrarian issues, including Franciszek Bujak, Władysław Grabski and Jerzy Kuncewicz. Secondly, by the Slavic Union of Rural Youth, which also included Polish organizations. The exchange of views took place both at the congresses of this association in Ljubljana (1924), Prague (1926), Poznań (1929) and Bratislava (1932), and during other forms of the organization's activities, including courses in Slavic folk culture. ${ }^{2}$ Thirdly, by the agency of the older generation of politicians representing the peasant movement, who had often been in personal contact with Czech and Slovak politicians, from the period of joint activity in the Austrian Parliament. Among other things, on the basis of these relations the International Agrarian Bureau, the so-called Green International was established in Prague in 1921. The Bureau was to organize contacts between the peasant parties of Europe. At the end of the 1920s, it consisted of 17 peasant parties from all over Europe, including the one from Poland - the Polish Piast Peasant Party. Also, a place to share thoughts was in the journal Grüne Internationale issued in Vienna (Kubu, Sousa, 2010, pp. 243-246).

On the basis of the ideas permeating from the outside and the considerations of domestic scientists, politicians and social activists in Poland developed three streams of agrarianism: academic, also known as non-political (Bujak, Grabski, Styś), landowning (Lutosławski, Jaworski, Listowski, and Rapacki) and Wici (Miłkowski, Niećko, Kuncewicz, Zaleski and Lutyk). Taking everything into account, the particular streams

2 The majority of Polish rural youth organizations embraced the ideological assumptions of the declaration of the Slavic Union of Rural Youth, adopted at its First Congress in Ljubljana in 1924, which among other things states that: "working on the land is the most important part of all human activities. The farmer, through all his creations, is a positive factor in society. Land being cultivated by man is the best guarantee of the nation and the state. One of the major aims of agrarianism is the holding of land by those who work it. The basis of agrarianism is peace, since only in peace can a farmer perform his mission for the benefit of mankind." See: Tokarczyk, 2000, pp. 238-44; Lis, no. 10, p. 315. 
had a lot in common, including the conviction of the great significance of agriculture and the exceptional relationship between farmers and the land cultivated by them, the necessity to repair the agrarian structure in Poland, and the opposition to Marxism and socialism. At the same time, they differed in attitudes to capitalism, private property and land reform, and also in their views on the role of peasants and landowners in the Polish history (Chrobak, 1998, pp. 158-169; Listowski, 1938, p. 936; Bujak, 1919).

Despite ongoing differences, the representatives of all trends in Polish agrarianism unanimously stressed the fundamental importance of land and labor as the two basic resources that Poland had in the interwar period. It must be pointed out that the agrarians noted both the economic and spiritual meaning of these resources. Their ideal of man was one living in the country, living from farming, and thereby being in close contact with nature.

Among the above mentioned streams of Polish agrarianism, the one that acquired the greatest significance was Wici agrarianism. It was formed in the early 1930s, in the circles of rural youth in Krakow and Warsaw that came together in the Wici Rural Youth Association of the Republic of Poland. Due to the environment in which it was created, it was named młodowiejski [Rural Youth] or wiciowy [Wici] agrarianism, after the name of the organization, and at the same time after the journal Wici that was issued by it. Wici agrarianism was the only one of the existing agrarian concepts in Poland that gained a large group of followers and had a significant impact on the history of the Polish peasant movement. ${ }^{3}$ Agrarianism turned out to be one of the most vivid concepts in the history of Polish political thought in the twentieth century, since it is present in political life to this day, forming the ideological basis for the present Polish People's Party.

A crucial period in the history of Polish agrarianism, and in particular for Rural Youth agrarianism was the publication in 1933-1936 of works by Aleksander Zaleski (Orkacz) titled Agraryzm. Próba izolacji i syntezy ludowej myśli politycznej [Agrarianism. An Attempt at Isolation and Synthesis of Peasant Political Thought], by Jerzy Kuncewicz titled $\mathrm{Na}$

${ }^{3}$ Agrarianism was the foundation for the political manifestoes of the following organizations: ZMW PR Wici [Wici Rural Youth Association of the Republic of Poland ] from 1935 to 1948, Stronnictwo Ludowe [Peasant Party] from 1935 to 1939, undergound Stronnictwo Ludowe Roch [Roch Peasant Party] during World War II and Polskie Stronnictwo Ludowe [Polish People's Party] from 1945 to 47; see: Lato, Stankiewicz, 1969, pp. 315, 336-37, 367-368, 370, 380, 450-452, 457-458. 
nowych drogach. Próba programu z uwzględnieniem potrzeby koniecznej przebudowy życia spolecznego i państwowego [On New Roads. An Attempt to Develop a Program Taking into Account the Need to Reconstruct Social and State Life] and by Stanisław Miłkowski titled Agraryzm jako forma przebudowy ustroju spotecznego [Agrarianism as a Form of Reconstruction of the Social Order], published in Krakow in 1934, and Walka o nowa Polske [Fight for a new Poland], published in Warsaw in 1936 (Zaleski, 1933; Kuncewicz, 1934; Miłkowski, 1934; Miłkowski, 1936). The works by Miłkowski, which presented the worldview and the objectives of the Rural Youth movement most completely, ensured his position as the leading representative of the Polish agrarianism. As well as the above mentioned authors, others that rendered great service for the development of the Polish agrarianism were: Niećko, Lutyk, Babski, Solarz, Młodożeniec and Załęski (Lech, 1991, p. 17; Miłkowski, 1934, pp. 8-9; Borkowski, 1966, p. 37).

Rural Youth agrarianism was eclectic in its nature. The authors drew from all the trends that emphasized the importance of the countryside and agriculture, and that intended to take action for the development and empowerment of the lower social strata. In this way, Rural Youth agrarianism referred to physiocratism, Christian philosophy and the Enlightenment, as well as to some liberal and socialist concepts. The representatives of Rural Youth agrarianism combined scientific inspirations with elements of folk culture, tradition and mysticism of nature. They also willingly made reference to the achievements of the highly esteemed academic and moral authorities living in the period from the eighteenth to the twentieth centuries.

In this group, the leading figures were Jean-Jacques Rousseau, Jean Charles Leonard Simonde de Sismondi, John Stuart Mill and Nikolai Frederik Severin Grundtvig. Considering the achievements of Rousseau, agrarians were particularly interested in his concept of the social contract, the glorification of peasants due to their close relationship with nature, the idea of education (as a process of the liberation of natural but hidden human abilities and desires), and his views of relativizing the institution of private land ownership (Żabko-Potopowicz, 1936, pp. 41-42; Russell, 2000, pp. 790-797).

On the other hand, from the so-called 'economic Romanticism' of Jean Charles Leonard Simonde de Sismondi they took the ideas of defending family-based peasant farming and crafts from the threat of capitalism, and also the criticism of ruthless competition and profit as the primary 
purpose of business. Additionally, they also voiced the demands for land reform and for the development of smallholder agriculture (as more efficient in terms of production) and for state interference in economic life in order to achieve an equitable distribution of income (Stankiewicz, 1987, p. 200; Simonde de Sismondi, 1978, p. 319).

From the achievements of John Stuart Mill agrarianism took over the idea of local self-governance as a public authority, and at the same time as a tool to raise and mobilize the masses, the conviction of the unique economic and educational role of the cooperative movement, and finally the thesis that private property will gradually evolve towards socialized property (Mill, 1965, vol. 2, p. 551; Lipiński, 1968, pp. 371-388).

In contrast to the concepts of Rousseau, Simonde de Sismondi and Mill, which became a part of Rural Youth agrarianism in a transformed form and were rarely referred to, the ideas and methods of Grundtvig, a Danish philosopher, politician and social activist, were frequently mentioned and applied in practice. First of all, reference was made to Grundtvig's idea of social democracy and the rebirth of the nation through the country and the peasant, and to national culture based on folk culture. A manifestation of the direct use of this thinker's achievements was the foundation of folk universities in Poland, as well as the use of his educational methods and promotion of the rural cooperative movement. The most distinguished exponent of Grundtvig's ideas was an educational activist, closely related to ZMW Wici, Ignacy Solarz, who went to Denmark several times (for the first time in 1922). In 1924-1939 he ran the Uniwersytet Ludowy [People's University] in Szyce near Krakow, and then (after 1931) in Gać Przeworska (Bron-Wojciechowska, 1986, pp. 52-54, 106).

In addition to the above mentioned names, the representatives of $\mathrm{Ru}-$ ral Youth agrarianism also alluded to other great moral authorities, such as Mahatma Gandhi and Leo Tolstoy, and so to people who proclaimed that a life of virtue, sacrifice and simplicity, in close contact with nature, will lead to the rebirth of humanity. Moreover, in the works by Miłkowski we can see inspiration drawn from the populist ideology of Alexander Herzen and Nikolai Chernyshevsky (Kudłaszyk, 1978, pp. 42-50; Lech, 1991, p. 10).

Agrarians also referred to Polish political and social thought. In their conceptions, we can find inspiration derived from the republican-democratic tradition, which was represented by Joachim Lelewel, Stanislaw Worcell and Piotr Ściegienny, who saw peasants as the major force in the agrarian revolution in Central-Eastern Europe (Lech, 1991, pp. 10-12). From social democratic thought, especially the so-called 'stateless social- 
ism' of Edward Abramowski, agrarians took the theses of the subjective nature of human existence and the necessity of moral transformation prior to any social changes, and also the ideas of self-organization and cooperation (Krawczyk, 1965, p. 97).

An additional profound influence that is visible in Rural Youth agrarianism is that of the so-called 'agrarian revisionism', which propagated the advantage of small farms over large-scale farming. The Polish representatives of this trend were Kazimierz Mokłowski, Władysław Gumplowicz and Zofia Daszyńska-Golińska (Lech, 1991, p. 11).

To a limited extent, agrarians also alluded to liberal ideas, especially with regard to the maintenance of private ownership of small farms and workshops, and also in the context of political reforms which, according to them, should aim at broadening and consolidating of economic and political freedom of the individual. In this way, agrarians manifested their opposition to totalitarian regimes and their excessive state intervention in social and economic life (Miłkowski, 1934, pp. 29-34; Ziembiński, 1960, pp. 135-136).

Wici agrarianism was also significantly influenced by the academic centers headed by the supporters of the peasant movement, i.e. Franciszek Bujak (an economic historian, from 1924 to 1930 the head of the selfestablished Department of Economics of Small Farms in the Agricultural Institute in Puławy) and Władysław Grabski (Polish Prime Minister in 1920 and from 1923 to 1925, the founder of the Institute of Rural Sociology at the Central School of Agriculture in Warsaw). Bujak and Grabski advocated ameliorating the backwardness of the Polish rural areas in relation to urban, industrial areas. They also called for changes in the agrarian structure and raising the social awareness of the peasantry. On the Polish lands, they promoted and creatively developed the concepts of the Swiss peasant activist, Ernst Laur, who argued for the superiority and sustainability of small-scale farming (Laur, 1938, pp. 241-258; Lech, 1991, p. 13; Borkowski, 1966, pp. 43-44).

Another concept adopted from academic circles was an original idea of Wiktor Bronikowski, who attempted to create a new interdisciplinary academic movement, 'social agronomy'. It was supposed to be a new way of exerting an educative and educational effect on peasants in order to raise this social group to a higher level of material, social and spiritual culture (Żabko-Potopowicz, Wieczorek, 1979, p. 90).

The above mentioned influences and borrowings played an important role, however, it was the impact of the Czechoslovakian ideas and models 
that was of greatest importance for the emergence and development of Polish agrarianism. The basic assumptions of Czech agrarianism were formulated by Hodža, Frankerberger, Matula and Švehla, who, among other things, believed that land is the basis of all existence, and together with the surrounding nature creates a certain type of man. Consequently, the social, economic and cultural life of the nation grows out of the land, and the most valuable social group are the peasants, who in addition to that, form the basis of democracy. Moreover, the peasant farms that were based on the work of the owner's family, together with co-operatives, were in his opinion, the basic organizational unit of agricultural production (Kowal, 1964, p. 44; Golec, 1994, p. 42).

The most prominent representative of Wici agrarianism, Miłkowski, was under the profound influence of Czech agrarianism. He translated the treatise by Hodža entitled: Agrarian democracy against the intellectual currents of the modern day, and in the preface to his work in 1934 he said that the experience of the Czech and Slovak peasant activists (Hodža in particular) should be the starting point for further activities aimed at developing the theory of agrarianism in Poland. In another work, Miłkowski wrote directly that "this term [agrarianism - T.J.] has come in a ready form from Czechoslovakia, where peasant thought stepped forward much further than with us ("Młoda Myśl Ludowa" nos. 4, 5, 6, 1932; Miłkowski, 1934, p. 7).

However, the creators of Polish agrarianism did not take the Czech models uncritically; they considered them too materialistic and detached from Polish conditions. Therefore, in referring to foreign models (ideas and experiences), they sought to develop their own original agrarian ideology, which by the end of the interwar period became much more radical than the Czech, Danish and Swiss ideals.

Taking everything into account, apart from the external influences, for all creators of this ideology, the starting point of formulating their concept for reform was the statement of fact that Poland was an agricultural country, in which over $70 \%$ of society lived in rural areas, and therefore the solution to socio-economic problems required in the first place resolving the problems of rural areas and agriculture. At the same time, all three of them (Bujak, Grabski, Miłkowski) claimed that land is a fundamental national resource, and peasants are the most important social group in Poland. According to them, the optimal use of those resources required a restructuring of property relations and distribution of land to landless peasants and small farm owners. The amount of the land suitable to be 
allotted was estimated at 3 million hectares, and the number of landless peasants and small farm owners at 5.5 million in 1938 (Mieszczankowski, 1983, pp. 56-57, 85).

Accordingly, they devoted much space in their deliberations to the question of land ownership and the plans to reconstruct property relations in Poland, as well as the role that the land and labor played in the lives of individuals and the whole society. While they differed on many issues, they were at the same time in agreement that in the conditions of the grave crisis (or even decline) of industrial capitalism, it was the land and labor that were to become the basis for the economic development of Poland, and a chance to overcome the economic crisis.

The main socio-economic postulates of Wici agrarianism resulted from the rejection of monopolistic capitalism, which was responsible for the crisis, and communism, which was a threat to peasant property and a negation of the hitherto property structure in Polish agriculture, industry and trade. Criticizing capitalism and communism, and their approaches to property, agrarians attempted to establish a socio-economic system which would remove the contradiction between capital and labor, and which would protect the workers against exploitation, and small owners (peasants in particular) against expropriation. This was to be a system that would be "adapted to human nature," a system which would "bind man with the results of his work and one which would guarantee economic development and a just distribution of national income" (Miłkowski, 1934, p. 43).

As was already mentioned, the concepts of agrarianism were discussed most extensively in the work of Miłkowski entitled Agraryzm jako forma przebudowy ustroju spolecznego [Agrarianism as a Form of Reconstruction of the Social Order], much of which was devoted to land and peasants and their role in the functioning of economy and society. According to Miłkowski, the principle of unrestricted and inviolable property leads to the exploitation and poverty of large social groups, and therefore he called for the "abandoning of private property where it becomes the source of exploitation and where social reasons require it." For obvious reasons, in his work he devoted most space and attention to agricultural issues. After having negated the hitherto agricultural structure, and recognizing the self-dependent peasant farm as the foundation of the future agricultural system, he said that land should "be transferred into the hands of those who work on it personally, and for whom it will be their workplace. No one can possess land who has not worked on it, and there should 
be no compensation paid to the former owners after the land reform" (Miłkowski, 1934, p. 49).

Miłkowski justified the peasants' right to land by the fact that their predecessors worked on the land of estate owners, and in the course of this work they had "paid even more" than its value. He also justified the necessity of division of large landed estates into small farms by the greater productivity of the latter (here he referred to Ernst Laur and Władysław Grabski's concept of decentralization of land) and to the attachment to "one's own piece of land" and to work on one's own, so deeply rooted in the peasant psyche. ${ }^{4}$

While glorifying small private farms, Miłkowski postulated a harmonious combination of land, capital and labor. At the same time, he noticed that land is a limited property that cannot be enlarged, therefore the productivity of a farm could be increased only by a greater amount of labor and capital. Since the 1930s was a time when there was a shortage of capital in the Polish countryside, virtually the only way to intensify production was the best use of labor resources (Miłkowski, 1934, p. 51).

Starting in 1935, Miłkowski's concept, combining the postulate of preservation of individual property (which would be subordinated to social interest, and which was not the basis of exploitation of one man by another), which demanded thorough changes in property structure in Poland, became a canon of agrarian thought and a part of the official ideology of the peasant movement.

The vision of the socio-economic modernization of Poland developed by Miłkowski and other agrarians did not concern only changes in the agricultural structure and the development of peasant farms, but it also applied to structural issues - institutional, technical and social awareness. Among other things, it assumed the creation of economic democracy, socialization of industry, which meant industry being taken over by cooperatives and economic self-governance, and finally the development of the cooperative movement, economic self-governance and economic planning (Miłkowski, 1966, p. 266).

Promoting the latter three institutions was associated with the agrarians' aim of economic life being based on an organized society. In par-

${ }^{4}$ Miłkowski referred in his articles to the work by Grabski - Wieś i folwark [The Country and the Farm], in which he presented the theory of decentralization in agriculture, which stated that in the conditions of free competition, small farms are at an advantage over large-scale ones. Here, he referred to the publication by Laur and his own research on the economics of agriculture. See: Grabski, 1930, pp. 17-45. 
ticular, the cooperative movement was supposed to fulfil any "technical, economic and organizational shortcomings and deficiencies" of small-scale farming, to remove go-betweens in agricultural trade, and also to shape peasants' awareness in the spirit of cooperation and self-organization (Lato, Stankiewicz, 1969, p. 451; Miłkowski, 1934, pp. 69-70).

According to agrarians, the structure of the economy was to consist of three main elements: privately owned farms (newly-created or formed by enlargement of former small farms as a result of land reform); nationalized factories (possibly located in rural areas); and co-operatives. ${ }^{3}$ All of these were to be included in the uniform system of the planned economy, in which agriculture and industry have the same importance and should be developed simultaneously (Lato, Stankiewicz, 1969, p. 315, 370).

At the same time, they opposed far-reaching state intervention in the economy, particularly rejecting flatly the solutions used in the Soviet Union and the Third Reich, which in their opinion, deprived the people of liberty and property. Therefore, despite some collectivist tendencies, it was stressed that every citizen should own, if not their workplace, then any useable property, such as land, a house, apartment or working plot, because "only this guarantees personal independence and forms the basis for a truly democratic system" (Lato, Stankiewicz, 1969, pp. 369-370). Taking into consideration private property, agrarianism propagated the necessity of subordinating it to the general public's interest. On the other hand, all forms of collective activity should be based on freedom of choice.

Agrarians realized that the proposed modernization of their socioeconomic system required a high level of awareness and commitment from all potential participants, especially the peasants. Therefore, the key objective of the Wici Rural Youth Union of the Polish Republic was the education and shaping of a new man, who would be capable of rebuilding social, economic and political relations in Poland according to agrarian recommendations (Łuczak, 1986, pp. 103-110, 123-135).

Therefore, the organization conducted wide-scale educational activities. It was through journals, readings, lectures and a self-study campaign that the Union propagated their ideas and strived to raise the level of education in the country. A special role was played by agricultural courses (which were mass courses) and folk universities (designed for the future leaders of rural social life), which were organized on the basis of the Danish model (Jakubiec, 1937, no. 1; Bieńkowska, 1936, no. 39).

Ideologically, agrarians not only considered economic and structural issues, but they also propagated the cult of land and respect for nature and 
their beneficial influence on the psyches of people working on the land. Accordingly, the transformation in the agricultural structure was supposed to bring a positive outcome in the economic as well as spiritual sphere of life, since from the agrarians' point of view, a farm was something more than just a subject of possession and a source of income, and working on the land was something more than a form of economic activity. A farm was a dynamic whole, a workplace, and at the same time it was the place of a close relationship between man and the land, the essence of which was working in the fields. On the one hand, man changes the land through his work, on the other hand, the land as a living reality changes man. Constant contact with nature has a decisive impact on the fate and psyche of man, and it develops his moral and physical health. According to Miłkowski, "a man of the land, drawing its vital sap, living in the sun and open air, is a symbol of health, vigor, spiritual balance and a specific outlook on the world." On the other hand, the agrarians were of the opinion that a lack of constant contact with nature, typical of urban societies, leads to degeneration and spiritual impoverishment (Miłkowski, 1934, pp. 37-39).

Consequently, on the one hand, agrarian thought had a strong ecological strand, and on the other hand, there was a noticeable anti-urban and anti-industrial attitude, which was based on the belief that industry exploits and destroys both nature and man. Urban life was, in the agrarians' opinion, contrary to the usual order of the world and nature. Additionally, technological expansion led to the dehumanization of man and made him a mere extension of a machine. Hence, the agrarians' calls to link the largest number of people working outside farming with the land which was a condition for regaining their "lost mental balance and overall development."

This does not mean, however, that agrarians' attitude to technical modernization was clearly negative. They condemned mechanization in the field of industrial production, because in their view it only served to maximize profits and "adversely affected the development of individual human values" (Gołębiewski, Jarecka-Klimowska, 1978, p. 113). At the same time, they were in favor of technical advancement in agriculture, as they understood that it determined economic development to a large extent, and also facilitated "relieving rural man of excessive physical work" (Miłkowski, 1934, p. 55). However, they added that "the achievements of technical progress [...] cannot be used for enrichment of single individuals, but to multiply the prosperity of the entire society" (Gołę- 
biewski, Jarecka-Klimowska, 1978, p. 113). Technical advancement in agriculture would be achieved through the development of cooperatives, creating engineering companies, and in favorable conditions production cooperatives, and, additionally, through land reclamation, enclosure, specialization, standardization and electrification (Gołębiewski, Jarecka-Klimowska, 1978, p. 114; Miłkowski, 1934, p. 55; Lech, 1991, p. 91).

The presence of ecology in agrarianism was not just an ideological stance but it was one of its most essential elements, since, as Miłkowski put it, agrarianism "grows out of the land and it boosts its significance" (Miłkowski, 1936, p. 47). The postulate of living in harmony with nature and making optimal use of renewable resources, such as the land and people, distinguished agrarianism from communism and capitalism, which stressed the harnessing of nature and its exploitation. In view of that fact, agrarians are thought to be the forerunners of ecological ideas.

\section{Conclusion}

When embarking in the early 1930 s on the creation of the Polish version of agrarianism, young peasant activists were convinced that the Peasants' Party, as the representative of peasants, that is the largest social group, should have a manifesto based on an original and modern ideology corresponding to the social role and aspirations of peasants. It aimed to unite the peasant movement, give it a new impetus in the fight against Sanacja [Sanation] and set out the goals and methods for the political and socio-economic modernization of Poland. ${ }^{5}$ Generally speaking, in the agrarian vision Poland was to be a country dominated by peasants and agriculture, with a mixed property system that would be devoid of any signs of exploitation, based on the cooperative movement and self-governance; a country with a cultural ethos based on folk culture values. That ideal was to be achieved by means of gradual voluntary transformations (revolution was rejected), allowing only occasional state interference.

5 Seeing the success achieved at that time by the fascist and communist movements, agrarians were convinced of the necessity of having a shaped worldview (ideology) as the basis for action. However, they rejected the underpinning ideology of those trends as totalitarian, since they themselves and the Peasant Party [SL] consistently advocated a democratic political system. Therefore, they sought a 'third way', between capitalism and communism. 
In the period from 1931 to 1939, Rural Youth agrarianism evolved from a moderate to a radical class ideology (in many ways similar to socialism). Then, during World War II and immediately thereafter (especially in the manifesto of PSL [Polish Peoples' Party] from 1946, Wici agrarianism took the form of a moderate nationwide ideology of 'the third way', which referred to ethics and Christian morality.

The concepts of land, man and labor were the basis of Wici agrarianism. Land played the role of a fundamental economic, structuring and cultural value, since in the cultural system of traditional Polish villagers, everything started and ended on the land, as the source of life and the place of eternal rest. In turn, working on the land, in constant contact with nature was a factor that positively shaped the human psyche. According to the agrarians, the proper use of land and labor resources would determine the economic and social development of Poland.

Agrarian concepts were contradictory to the dominant idea at that time of modernization through industrialization, which assumed the extensive use of mineral resources, and coal in particular. Therefore, agrarians were accused of naivety, economic dilettantism, overestimating the role of peasants, and being guided by emotions, where economic calculation should prevail. However, the above critical judgment seems too harsh as, despite the agrarians' unquestionable attachment to the countryside, they realistically evaluated the character, and strong and weak points of the Polish economy of the 1930s. According to them, when facing the crisis of industrial capitalism, the collapse of the international division of labor and lack of investment capital, the only real chance for an economic boom in Poland was the development of the domestic market through the use of the available land and labor resources.

For this purpose, it was, in their opinion, necessary to carry out land reform, as possession of your own farm was, for peasants, a prerequisite for effective work and becoming part of the market economy. Additionally, it gave them a sense of independence from the violence of capital and political power. Against this background, land reform was a necessary step towards connecting the land with labor, and making optimal use of both of them.

Agrarianism was an important concept in Polish political thought of the interwar period. Its creators did not come into power, but by their political, economic and educational activities they contributed to changes in the social awareness of the rural population, including the development of self-organization and cooperatives, and also strengthening the spirit of 
good citizenship and democracy among peasants. On the other hand, the radical socio-economic demands of the agrarians compelled other political forces that were seeking farmers' support to modify their political manifestoes and adopt many approaches similar to agrarian ones.

\section{References}

Bauerngesellschaften auf den Weg in die Moderne. Der Agrarismus in Ostmitteleuropa 1880-1960 (2010), Hrsg. Von H. Schultz, A. Harre, Wiesbaden.

Bełch J. (1939), Katolickie odrodzenie wsi, Poznań.

Bieńkowska H. (1936), Do postęu przez spółdzielczość, "Wici”, nr 39.

Borkowski J. (1966), Wizje społeczne i zmagania wiciarzy w świetle młodzieżowej prasy ludowej 1928-1939. "Wici", Znicz, Spotem, Młoda Myśl Ludowa, Chłopskie Życie Gospodarcze, Warszawa.

Bron-Wojciechowska A. (1986), Grundtvig, Warszawa.

Bujak F. (1919), O naprawie ustroju rolnego w Polsce, Kraków.

Chrobak T. (1998), Filozoficzne przestanki agraryzmu. Studium wybranych zagadnień, Rzeszów.

Chałasiński J. (1938), Młode pokolenie chłopów. Procesy i zagadnienia kształtowania się warstwy chlopskiej w Polsce, Warszawa.

Dąbrowski S. (1981), Koncepcje przebudowy Polski w programach i publicystyce ruchu ludowego 1939-1945, Warszawa.

Golec A. (1994), Agrarystyczne koncepcje gospodarcze, Lublin.

Gołębiewski E., Jarecka-Klimowska S. (eds.) (1978), Związek Młodzieży Wiejskiej $R P$ "Wici". W walce o postęp i sprawiedliwość społeczna. Wybór dokumentów 1928-1948, Warszawa.

Grabski W. (1930), Wieś i folwark. Drobne i duże gospodarstwa rolne ze stanowiska ekonomicznego, Warszawa.

Jachymek J. (1993), Neoagraryzm i trzecia droga. Przebudowa i walka o nowa Polskę, Lublin.

Jakubiec J. (1937), Jak żyja w Danii, “Zielony Sztandar”, no. 1.

Kubu E., Sousa J. (2010), Die Wiener Grüne Internationale - eine mitteleuropäische Transfergeschichte?, in: Bauerngesellschaften auf den Weg in die Moderne. Agrarismus in Ostmitteleuropa 1880-1960, eds. H. Schultz, A. Harre, Wiesbaden.

Kuncewicz J. (1934), Na nowych drogach. Próba programu z uwzględnieniem potrzeby koniecznej przebudowy życia spolecznego i państwowego, Cieszyn.

Kudłaszyk A. (1978), Myśl spoleczno-polityczna Bolesława Wystoucha 1885-1937, Warszawa-Wrocław.

Krawczyk Z. (1965), Socjologia Edwarda Abramowskiego, Warszawa. 
Lato S., Stankiewicz W. (1969), Programy stronnictw ludowych, Warszawa.

Laur E. (1938), Wytyczne linie programu Szwajcarskiego Zwiazku Chłopskiego, "Wieś i Państwo", no. 4.

Lech A. (1991), Agraryzm wiciowy, Łódź.

Lipiński E. (1968), Historia powszechnej myśli ekonomicznej do roku 1870, Warszawa.

Lis J. (1968), Słowiański Związek Młodzieży Wiejskiej, "Roczniki Dziejów Ruchu Ludowego", no. 10.

Listowski A. (1938), Uwagi ogólne o zagadnieniach ustroju rolnego, in: Księga Pamiątkowa na 75 lecie Gazety Rolniczej, 1861-1935, Księga wsi polskiej. Źródła, dzieje i kierunek jej kultury, ed. J. Lutosławski, Warszawa, vol. II.

Kowal J. (1964), “Wici”. Powstanie i działalność społeczno-wychowawcza 1927-1939, Warszawa.

Łuczak A. (1986), Związek Młodzieży Wiejskiej Rzeczypospolitej Polskiej 1928-1939, in: Przed "Wiciami” i po "Wiciach”, ed. K. Przybysz, Warszawa.

Mieszczankowski M. (1983), Rolnictwo II Rzeczypospolitej, Warszawa.

Mill J. S. (1965), Zasady ekonomii politycznej i niektóre jej zastosowania do filozofii społecznej, Warszawa.

Miłkowski S. (1934), Agraryzm jako forma przebudowy ustroju społecznego, Kraków.

Miłkowski S. (1936), Walka o nowa Polskę, Warszawa.

Miłkowski S. (1988), Pisma publicystyczne 1930-1939, zebrał i oprac. W. Piatkowski, Warszawa.

„Młoda Myśl Ludowa” nos. 4, 5, 6, 1932.

Piątkowski W. (1993), Wokół idei agraryzmu, Warszawa.

Russell B. (2000), Dzieje filozofii zachodu, Warszawa.

Simonde de Sismondi J. C. L. (1978), Teoria ekonomiczna, Warszawa.

Stankiewicz W. (1987), Historia myśli ekonomicznej, Warszawa.

Tokarczyk R. (2000), Współczesne doktryny polityczne, Kraków.

Wojas A. (1983), Problematyka agrarna w polskiej myśli politycznej 1918-1948, Warszawa.

Zaleski (Orkacz) A. (1933), Agraryzm. Próba izolacji i syntezy ludowej myśli politycznej, Warszawa.

Ziembiński J. (1960), Z zagadnień genezy i podstawowych założeń ideowo-politycznych agraryzmu w Polsce, "Roczniki Dziejów Ruchu Ludowego", no. 2, pp. 106-147.

Związek Młodzieży Wiejskiej RP “Wici”. Wwalce o postęp i sprawiedliwość społeczną. Wybór dokumentów 1928-1948 (1978), eds. E. Gołębiewski, S. JareckaKlimowska, Warszawa.

Żabko-Potopowicz A. 1936), Agraryzm. Encyklopedia nauk politycznych, Warszawa. 
Żabko-Potopowicz A., Wieczorek T. (1979), Wiktor Bronikowski o agronomii spotecznej. Wybór i komentarze, Warszawa.

\section{Ziemia uprawna i ludzie jako podstawowe zasoby II Rzeczpospolitej w koncepcjach polskich agrarystów (1931-1946)}

\section{Streszczenie}

Agraryzm powstał w Niemczech w drugiej połowie XIX wieku, jednak największe wpływy osiągnął w przeważnie rolniczych krajach Europy Środkowej i Wschodniej. Srodkowoeuropejski agraryzm był ideologią chłopów i głosił, że ziemia jest największym bogactwem narodu, rolnictwo najważniejszą gałęzią gospodarki, a chłopi najzdrowszą moralnie, a tym samym najcenniejszą częścią społeczeństwa. Agraryzm był ideologią personalistyczną, która głosiła koncepcję człowieka jako podmiotu życia społecznego i gospodarczego. Dlatego krytykował zarówno skrajny liberalizm, jak i totalitarne koncepcje ustrojowe oraz głosił koncepcję "trzeciej drogi rozwoju" pomiędzy kapitalizmem a komunizmem. Głównym celem niniejszego artykułu jest przedstawienie kształtowania się i rozwoju polskiego agraryzmu oraz związanego $\mathrm{z}$ tym procesu transferu i recepcji wiedzy. W centrum analizy znajduje się koncepcja ziemi, człowieka i pracy sformułowana przez przedstawicieli głównego nurtu tej ideologii. W latach trzydziestych dwudziestego wieku polscy agraryści opowiadali się za reformą rolną i podziałem gruntów rolnych pomiędzy małe rodzinne gospodarstwa rolne, które ich zdaniem w optymalny sposób wykorzystywały ziemię, kapitał i pracę, czyli najważniejsze zasoby, jakimi dysponowała międzywojenna Polska.

Slowa kluczowe: agraryzm, trzecia droga, ziemia, praca, transfer wiedzy 